\title{
MENEROPONG TIPOLOGI BAHASA-BAHASA DI PAPUA: SUATU TINJUAN SINGKAT
}

\author{
Yusuf Sawaki \\ Center for Endangered Languages Documentation (CELD) \& \\ Fakultas Sastra dan Budaya, Universitas Papua \\ ysawaki@fulbrightmail.org
}

\begin{abstract}
Tanah Papua, which includes the provinces of Papua and West Papua, is the most diverse linguistic region in Indonesia. Out of 760 languages in Indonesia, Tanah Papua has about 270 languages. The diversity of languages is not only about the number of languages but also about the linguistic features. Languages in Tanah Papua are divided into two major groups, which are Austronesian and non-Austronesian (known as Papuan) languages. Both major linguistic groups contribute diverse linguistic features ranging from phonological system, word, phrase, clause and sentence structures, as well as diversity of semantic and pragmatic structures. The linguistic diversity is also determined by a contact language history in the region that has been occurred for centuries, especially in the regions of Jayapura and the Bird's Head of New Guinea. Although the region is linguistically rich, not many linguistic reseach has been done in the region. We therefore do not have a comprehensive understanding about languages in Papua yet. The purpose of this paper is to give a brief description about grammatical features of languages in Tanah Papua.
\end{abstract}

Key words: Tanah Papua, Austronesian, non-Austronesian, grammatical features

\begin{abstract}
Abstrak
Wilayah Tanah Papua, baik Provinsi Papua dan Papua Barat merupakan wilayah yang memiliki jumlah bahasa terbanyak di Indonesia. Kurang lebih 270-an bahasa daerah terdapat di Tanah Papua dari jumlah bahasa secara keseluruhan di Indonesia yaitu 760an. Bukan hanya dari sisi jumlah bahasa daerah saja, bahasa-bahasa di Tanah Papua juga memiliki sifat-sifat gramatika bahasa yang sangat beragam. Bahasa-bahasa di Tanah Papua terdiri dari dua kelompok besar yaitu bahasa kelompok Austronesia dan kelompok non-Austronesia. Dua kelompok besar bahasa ini menyumbangkan sifat-sifat gramatika yang sangat beragam mulai dari sistem bunyi, struktur kata, struktur frasa, struktur kalimat, kata ganti orang, struktur makna sampai pada keragaman pragmatis dalam penggunaan bahasa. Keragaman ini juga dipengaruhi oleh sejarah kontak bahasa yang telah berlangsung berabad-abad di wilayah Jayapura dan di wilayah Kepala Burung Papua. Meskipun demikian, penelitian-penelitian linguistik belum banyak dilakukan sehingga kita dapat memiliki gambaran linguistis yang baik tentang bahasabahasa di Papua. Tujuan penulisan ini adalah memberikan gambaran singkat tentang karakteristik gramatika bahasa-bahasa di Tanah Papua.
\end{abstract}

Kata kunci: Tanah Papua, Austronesia, non-Austronesia, sistem gramatika

\section{PENDAHULUAN}

Wilayah Papua merupakan wilayah dengan tingkat keragaman bahasa tertinggi di Indonesia. Tingkat keragaman bahasa-bahasa di Papua bukan hanya dari sisi jumlah bahasa saja tetapi juga 
keragaman dalam ciri-ciri linguistis. Kealamian wilayah ekologi dari pulau-pulau kecil, pesisir pantai, dataran rendah, pegunungan tinggi sampai pada puncak-puncak bersalju membuat keragaman ini sangat tinggi karena kehidupan masyarakat Papua yang hidup terisolir antar satu kelompok dan kelompok lain, antar satu bahasa dengan bahasa lain. Sistem kebudayaan dan sistem sosial juga memberikan kontribusi yang nyata terhadap keragaman bahasa-bahasa di Papua. Selain itu, kontak bahasa di beberapa wilayah di Papua juga membuat percampuran ciriciri linguistik bahasa yang menambah tingkat keragaman bahasa ini.

Tulisan ini adalah studi pustaka dari penelitian-penelitian yang pernah dilakukan di Tanah Papua, sekaligus merupakan tinjauan deskriptif yang bertujuan untuk memberikan gambaran tentang situasi dan tipologi kebahasaaan di Papua secara singkat dan mendalam bagi mereka yang berminat meneliti bahasa-bahasa di Papua atau berminat mempelajari situasi bahasa-bahasa di Papua. Tulisan ini juga dapat digunakan sebagai bahan untuk mengembangkan instrumen pengambilan data dengan memiliki wawasan awal tentang bahasa-bahasa di Papua secara umum maupun bahasa tertentu yang akan diteliti secara khusus. Tulisan ini terutama memberikan gambaran tentang tipologi struktur tata bahasa dari dua rumpun bahasa utama di Papua, yaitu rumpun bahasa Austronesia dan Non-Austronesia (atau Papua). Diharapkan bahwa dengan gambaran tipologi bahasa ini, peneliti dapat memiliki pengetahuan awal tentang bahasa yang akan diteliti - ke dalam rumpun mana bahasa itu dimasukkan dan bagaimana sistem struktur tata bahasanya.

\section{RUMPUN BAHASA DAN SITUASI EKOLOGI BAHASA DI PAPUA}

Sebelum sifat-sifat gramatika bahasa-bahasa di Papua dijelaskan secara mendalam, ada baiknya kondisi kebahasaan di Papua dipaparkan terlebih dahulu agar kita mendapatkan gambaran yang jelas tentang bahasa-bahasa di Tanah Papua. Bahasa-bahasa di Papua dibagi ke dalam dua rumpun utama, yaitu bahasa-bahasa Austronesia dan bahasa-bahasa non-Austronesia, atau disebut juga bahasa-bahasa Papua (lihat Foley, 1986 \& 2000). Pembagian kedua rumpun bahasa ini bukan hanya dilihat dari sisi pendekatan linguistik historis saja, melainkan juga dari sini pendekatan tipologi yang melihat sifat-sifat gramatika. Pendekatan linguistik historis memberikan bukti bahwa kedua rumpun utama ini memiliki sejarah yang berbeda. Bahasabahasa Austronesia berasal dari satu nenek moyang bahasa yaitu Proto-Austronesia yang berasal dari Taiwan dan kemudian menyebar ke kawasan yang sangat luas, yaitu dari Taiwan di utara sampai Selandia Baru di selatan dan dari Kepulauan Paskah (Easter Island) di Timur sampai di Madagaskar di sebelah barat yaitu di pantai timur benua Afrika (lihat Blust, 1993, 2009; Ross, 2004; Pawley \& Ross, 1993). Mayoritas bahasa-bahasa di Indonesia masuk ke dalam rumpun Austronesia, kecuali beberapa bahasa di Kepulauan Alor dan Pantar, Halmahera Utara, dan sebagian besar bahasa-bahasa di Tanah Papua yang dikategorikan ke dalam bahasa nonAustronesia (atau Papua).

Bahasa-bahasa di Papua yang masuk dalam rumpun Austronesia terletak di pesisir pantai utara dan pulau-pulau sekitarnya, mulai dari pesisir pantai Jayapura, Sarmi dan Teluk Cenderawasih, serta Kepulauan Raja Ampat. Bahasa-bahasa ini dibagi ke dalam dua subkelompok yaitu South Halmahera-West New Guinea (SHWNG) dan Oceania. Bahasa-bahasa di sekitar Jayapura dan Sarmi seperti bahasa Tobati, Kayu Pulo, Ormu (di Jayapura), Bonggo, Wakde, Anus, Yarsun, Kodena (di Sarmi) merupakan bahasa-bahasa yang masuk sub-kelompok Oceania. Yang masuk ke dalam sub-kelompok South Halmahera-West New Guinea adalah 
Waropen, Ambai, Ansus, Wooi, Pom, Serui Laut, Munggui, Kurudu, Moor, Biak, Roon, Wandamen, Dusner, Yaur (di Teluk Cenderawasih), Ambel, Maya, Batanta, Matbat (di Kepulauan Raja Ampat) dan kemungkinan bahasa Austronesia di sebelah barat daya Papua seperti bahasa Irarutu, Sekar, Kuri, Mor (di Semenanjung Bomberai) (Ross, 1996; Remijsen, 2002; Mofu, 2008; Karubaba, 2008 dan Kamholz, 2014).

Bahasa-bahasa non-Austronesia (Papua) adalah bahasa-bahasa yang tidak berasal dari satu nenek moyang bahasa, tetapi terdiri dari banyak keluarga bahasa sendiri-sendiri. Diprediksi kurang lebih terdapat 60 keluarga bahasa yang termasuk dalam rumpun bahasa Papua. Mayoritas bahasa-bahasa Papua ini berada di Pulau Besar New Guinea (lihat Foley, 1986, 2000). Di Tanah Papua, bahasa-bahasa ini dibagi dalam tiga keluarga bahasa, yaitu Trans-New Guinea, West Papua, dan Geelvink Bay.

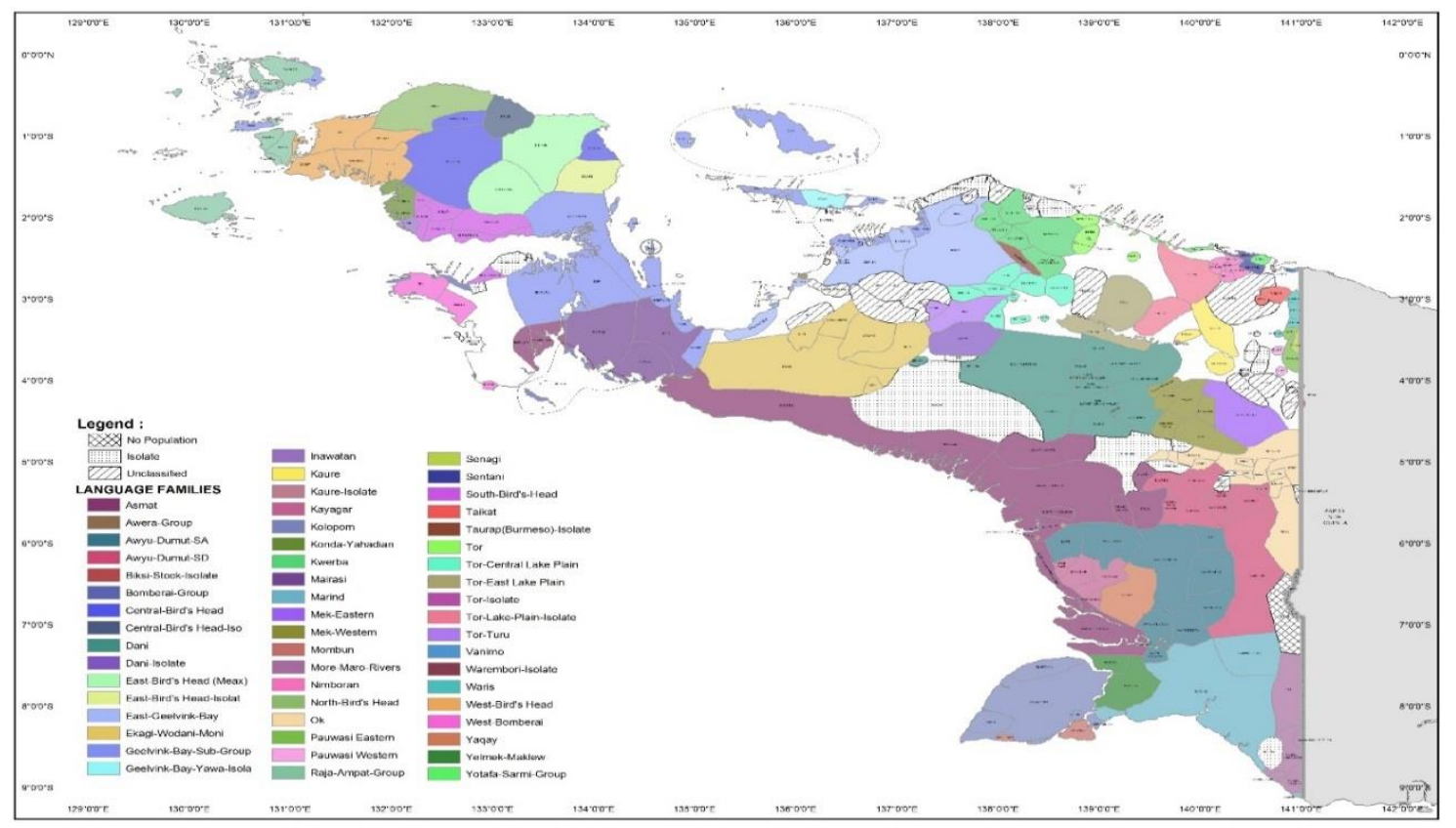

Peta 1. Klasifikasi bahasa-bahasa di Papua (sumber: SIL 2004)

Mayoritas bahasa-bahasa Papua di Tanah Papua masuk dalam keluarga bahasa TransNew Guinea yang meliputi daerah persebaran di wilayah Pegunungan Tengah, Wilayah Selatan, Wilayah Utara mulai dari daerah perbatasan PNG-RI, wilayah Mamta, dan sebagian Mamberamo bagian utara, wilayah daratan leher Kepala Burung Papua dan wilayah selatan Kepala Burung. Bahasa-bahasa seperti bahasa Dani, Yali, Mek, Mee, Asmat, Marind, Muyu, Mandobo, Sentani, Nafri, Demta, Isirawa, Kwerba, Auye, Mairasi, Mer, Tanah Merah, dan Inanwatan, Sebrar, Konda, Kais, Kokoda adalah bahasa-bahasa Trans-New Guinea.

Bahasa-bahasa yang dikelompokkan ke dalam keluarga bahasa rumpun Papua Barat (West Papua) adalah bahasa-bahasa yang berada di Kepala Burung Tanah Papua, seperti bahasa Hatam, Meyah, Sougb, Irires, Miyach, Maybrat, Kalabra, Moi, Abun, Moraid, Mpur, dan lainlain. Sedangkan bahasa-bahasa yang dikelompokkan ke dalam keluarga bahasa Geelvink Bay adalah bahasa-bahasa Papua yang berada di wilayah bagian barat dari daratan Mamberamo ke wilayah Waropen, dan beberapa bagian di wilayah Nabire dan Pulau Yapen. Bahasa-bahasa seperti bahasa Kirikiri, Demisa, Fayu, Iau, Biritai, Burate, Awera, Tarunggare, Onate, dan lainlain masuk dalam keluarga bahasa ini. 
Secara ekologi bahasa, bahasa-bahasa non-Austronesia dari kelompok Trans New Guinea merupakan bahasa yang dominan karena daerah penyebarannya yang sangat luas, baik dari jumlah bahasanya maupun jumlah penuturnya. Bahasa ini juga menyumbangkan karakteristik bahasa yang sangat beragam meskipun dalam beberapa hal terdapat persamaanpersamaan antar bahasa. Gambaran tentang karakteristik bahasa Trans New Guinea ini akan dibahas di bagian 3. Kelompok bahasa Austronesia juga beragam meskipun tidak serumit bahasa Trans New Guinea. Karakteristik linguitis bahasa-bahasa Austronesia ini sederhana dan juga dapat dilihat secara rinci di bagian 3. Bahasa non-Austronesia dari kelompok Geelvink Bay yang meliputi bahasa-bahasa di daratan dan aliran Sungai Mamberamo dan sekitar daerah Waropen adalah bahasa-bahasa yang sangat terisolir di daerah dataran rendah berawa yang dialiri sungai-sungai yang banyak. Bahasa-bahasa ini hampir merupakan bahasa bunyi (tonal languages) yang sistem morfologinya tidak serumit bahasa-bahasa Trans New Guinea, tetapi mempunyai sistem fonologi suprasegmetal yang sangat rumit, yaitu sistem bunyi (tone)nya berkisar antara 3 sampai 9 tone.

Yang menarik adalah bahasa-bahasa non-Austronesia yang berada di wilayah Kepala Burung Papua, seperti bahasa Hatam, Meyah, Maybrat, Mpur, Abun, Moi, dan lain-lain. Bahasa-bahasa ini memiliki sifat-sifat gramatika yang mirip dengan bahasa-bahasa Austronesia. Kemiripan ini disebabkan oleh kontak bahasa yang sudah terjadi berabad-abad. Kontak bahasa ini telah terjalin bersamaan dengan penyebaran manusia Austronesia ke timur ke pulau New Guinea dan juga ke Pasifik (Ross, 2009; Conroy, 2013; Donohue 2011). Kontak bahasa ini menyebabkan perubahan-perubahan sifat gramatika bahasa-bahasa Papua di Kepala Burung menjadi mirip sifat grammatika bahasa Austronesia, meskipun bahasa-bahasa ini juga masih memiliki sifat grammatika bahasa Papua.

\section{TIPOLOGI BAHASA-BAHASA DI PAPUA}

Selain tinjauan klasifikasi bahasa secara historis, bahasa Austronesia dan Papua dapat juga dikelompokkan berdasarkan tipologi struktur tata bahasa. Struktur tata bahasa dimulai dari struktur fonologi, morfologi, sintaksis dan semantik. Secara singkat, struktur-struktur tata bahasa ini akan dijelaskan berikut ini.

Struktur fonologi bahasa-bahasa di Papua berbeda satu dengan yang lainnya. Jumlah fonem vokal dan konsonan berbeda anatara satu bahasa dan bahasa lainnya. Belum pernah ada penelitian secara rinci untuk menjelaskan tipologi struktur fonlogi bahasa Austronesia dan nonAustronesia. Meskipun demikian, penelitian linguistik historis tentang bunyi-bunyi fonologis yang mencerminkan nenek moyang bahasa (proto-bahasa) di kelompok bahasa Austronesia dan non-Austronesia sudah banyak dilakukan (Ross 1996, 2004; Blust 2009, Pawley, 2007). Secara gamblang, Foley (2000) menyatakan bahwa sistem susunan bunyi pada bahasa-bahasa di Papua terbilang sederhana. Yang paling sederhana antara lain bahasa Obokuitui (daratan rendah Mamberamo) yang hanya memiliki 11 fonem. Secara umum susunan fonem berkisar antara 2035 fonem (vokal, diftong dan konsonan). Susunan bunyi vokal sangat sederhana dan terdiri dari lima bunyi vokal dasar yaitu i, u, o, e, a. Beberapa variasi (alofon) ditemukan di beberapa bahasa tetapi tidak memberikan dampak fonemis terhadap susunan bunyi-bunyi vokal dasar dimaksud. Susunan konsonan di bahasa-bahasa di Papua bervariasi tetapi juga sederhana. Sebagai contoh, bahasa Wooi di Yapen memiliki 13 konsonan (Sawaki, 2017), bahasa Biak: 14 konsonan (Heuvel 2006), Tobati: 19 konsonan (Donohue 2002), bahasa Hatam: 22 konsonan 
(Reesink 1999), bahasa Meyah: 15 konsonan (Gavelle, 2004). Untuk bahasa Austronesia, konsonan umumnya terjadi di tempat artikulasi yaitu bilabial, alveolar dan velar. Ciri ini dapat dilihat pada bahasa Wooi dan bahasa Biak. Di beberapa tempat artikulasi lain sangat jarang.

Tabel 1. Fonem konsonan bahasa Wooi (Sawaki, 2017)

\begin{tabular}{|c|c|c|c|c|c|c|c|c|c|c|}
\hline \multicolumn{11}{|c|}{ Fonem konsonan } \\
\hline & \multicolumn{2}{|c|}{ Bilabial } & \multicolumn{2}{|c|}{ Alveolar } & \multicolumn{2}{|c|}{ Palatal } & \multicolumn{2}{|c|}{ Velar } & \multicolumn{2}{|c|}{ Glottal } \\
\hline Stop & $\begin{array}{c}\mathrm{p} \\
(\mathrm{p})\end{array}$ & $\begin{array}{c}\mathrm{b} \\
\text { (b) }\end{array}$ & $\begin{array}{c}\mathrm{t} \\
(\mathrm{t})\end{array}$ & $\begin{array}{c}\mathrm{d} \\
\text { (d) }\end{array}$ & & & $\begin{array}{c}\mathrm{k} \\
(\mathrm{k})\end{array}$ & & & \\
\hline Nasal & & $\begin{array}{c}\mathrm{m} \\
(\mathrm{m})\end{array}$ & & $\begin{array}{c}\mathrm{n} \\
(\mathrm{n})\end{array}$ & & $\begin{array}{c}\mathrm{n} \\
\text { (ny) }\end{array}$ & & $\begin{array}{c}\eta \\
(\mathrm{ng})\end{array}$ & & \\
\hline Fricative & & $\begin{array}{c}\beta \\
(\mathrm{v})\end{array}$ & $\begin{array}{c}\mathrm{s} \\
\text { (s) }\end{array}$ & & & & & & $\begin{array}{c}\mathrm{h} \\
(\mathrm{h})\end{array}$ & \\
\hline Affricate & & & & & $\begin{array}{l}\mathrm{c} \\
\text { (c) }\end{array}$ & & & & & \\
\hline Trill & & & & $\begin{array}{c}\mathrm{r} \\
(\mathrm{r})\end{array}$ & & & & & & \\
\hline Glides & $\begin{array}{c}\mathrm{w} \\
(\mathrm{w})\end{array}$ & & & & $\begin{array}{c}\mathrm{j} \\
(\mathrm{j})\end{array}$ & & & & & \\
\hline
\end{tabular}

Tabel 2. Fonem konsonan bahasa Biak (Heuvel, 2006)

\begin{tabular}{|c|c|c|c|c|c|c|}
\hline & & Bilabial & Labio-dental & Alveolar & Palatal & Velar \\
\hline Stop & voiced & $\mathrm{b}(\mathrm{b})$ & & $\mathrm{d}(\mathrm{d})$ & & \\
\hline & voiceless & $\mathrm{p}(\mathrm{p})$ & & $\mathrm{t}(\mathrm{t})$ & & $\mathrm{k}(\mathrm{k})$ \\
\hline Nasal & & $\mathrm{m}(\mathrm{m})$ & & $\mathrm{n}(\mathrm{n})$ & & \\
\hline Fricative & voiced & $\mathrm{B}(\mathrm{v})$ & & & & \\
\hline & voiceless & & $\mathrm{f}(\mathrm{f})$ & $\mathrm{s}(\mathrm{s})$ & & \\
\hline Lateral & & & & $1(\mathrm{l})$ & & \\
\hline Trill & & & & $\mathrm{r}(\mathrm{r})$ & & \\
\hline Approximant & & $\mathrm{w}(\mathrm{w})$ & & & $\mathrm{j}(\mathrm{y})$ & \\
\hline
\end{tabular}

Untuk bahasa Papua, konsonan hampir terjadi di seluruh tempat artikulasi yaitu di bilabial, alveolar, palatal, velar. Sebagaimana dilihat di susunan konsonan bahasa Meyah (Gravelle 2004).

Tabel 3. Fonem konsonan bahasa Meyah (Gravelle, 2004)

\begin{tabular}{|c|c|c|c|c|c|c|}
\hline & & Bilabial & Alveolar & Palatal & Velar & Glottal \\
\hline Plosive & voiceless & & $\mathrm{t}$ & $\mathrm{t} \Sigma(\mathrm{c})$ & $\mathrm{k}$ & \\
\hline & voiced & $\mathrm{b}$ & $\mathrm{d}$ & $\mathrm{dZ}(\mathrm{j})$ & $\mathrm{g}$ & \\
\hline Fricative & & $\div(\mathrm{f})$ & $\mathrm{s}$ & & & $\mathrm{h}$ \\
\hline Nasal & & $\mathrm{m}$ & $\mathrm{n}$ & & & \\
\hline Liquid & & & $\mathrm{r}$ & & & \\
\hline Approximant & & $(\mathrm{w})$ & & $(\mathrm{y})$ & & \\
\hline
\end{tabular}

Karateristik suprasegmental cukup tinggi dan bervariasi, mulai dari level kata sampai pada level sintaksis. Untuk stress, pada umumnya bahasa-bahasa di Papua memiliki penultimate dan final word stress. Jejak tone (karakteristik tonal) dapat dilihat di banyak bahasa mulai dari 
level kata sampai kalimat. Bahasa-bahasa Papua kelompok Lakes Plains di sekitar daratan Sungai Mamberamo memiliki karakteristik tonal yang cukup tinggi dan sangat penting dalam bahasa mereka. Untuk semua bahasa yang masuk dalam kategori Lakes Plains bagian barat, tone jauh lebih penting dari pada morfologi (Clouse, 1993:19).

Sistem tata bahasa utama yang membedakan bahasa Austronesia dan bahasa nonAustronesia (Papua) adalah struktur dasar klausa, yaitu susunan subjek, predikat dan objek (SPO). Bahasa-bahasa Austronesia memiliki susunan struktur dasar klausa SPO. Sedangkan bahasa-bahasa Papua memiliki susunan struktur dasar klausa SOP, dengan pengecualian pada bahasa-bahasa Papua dari kelompok keluarga bahasa West Papua. Kelompok bahasa ini memiliki struktur dasar klausa SPO, yang sama dengan bahasa-bahasa Austronesia. Bahasa Yali (Sawaki, 1998, 2002), Marind (Ndiken, 2011), Wooi (Sawaki, 2017), Biak (Mofu, 2008), Maybrat (Dol, 2007), dan Hatam (Reesink, 1999) memberikan contoh perbedaan struktur dasar klausa sebagai berikut:

Yali (Papua - Trans New Guinea) - SOP

(1) n-ami-en an nu- wa-r-eh- ek

1s-paman-AGT 1s 1s-OBJ-pukul-REAL-NPAST-3s

'Paman saya memukul saya tadi'

Marind (Papua - Trans New Guinea)

(2) Nok m-ngge Ø-amuk oh

1SBJ PRS-1PL.SBJ>2SG.OBJ 2SG.OBJ-pukul 2OBJ

'Kita memukul anda'

Wooi (Austronesia - Teluk Cenderawasih) - SPO

(3) Agushen-dora Hendrikna ramdempe

Agus 3PL-pukul Hendrik LOC kemarin

'Agus dan teman-teman memukul Hendrik kemarin'

Biak (Austronesia - Teluk Cenderawasih)

(4) Susan dor romawasya

Susan d-or romawa-sya

Susan 3SG-panggil anak-Det.PL.AN

'Susan memanggil anak-anak itu'

Maybrat (Papua - West Papuan) - SPO

(5) Ana $\phi$-sayim ania

3P $\varnothing$-bagi sendiri

'Mereka saling membagi (sesuatu)'

Hatam (Papua - West Papuan) - SPO

(6) I-ngot igy-a.

3PL-ikat rumah-CIT

'Mereka membangun rumah.'

Selain struktur dasar klausa, struktur lainnya juga memberikan perbedaan antara bahasa-bahasa Austronesia dan Papua, yang dapat dijelaskan sebagai berikut. Struktur kata kerja merupakan inti dari klausa dasar pada bahasa-bahasa di Papua baik bahasa Austronesia maupun bahasa Papua. Kata kerja dapat menjadi satu klausa sederhana karena morfem-morfem dalam kata kerja merujuk pada struktur dasar klausa yaitu subjek dan predikat (dan juga objek), seperti contoh dalam bahasa Yali (Sawaki, 1998) dan bahasa Ambai (Karubaba, 2008) berikut ini. 
Yali (Sawaki, 1998):

(7) nu-wa-r-eh-esa

1SG.OBJ-pukul-REAL-NR.PST-3SG.SUBJ.PST

'Mereka memukul saya tadi.'

Ambai (Karubaba, 2008):

(8) $i$-madu

1SG.SUBJ-bicara

'Saya berbicara'

Meskipun demikian, terdapat perbedaan antara kata kerja bahasa Austronesia dan kata kerja bahasa Papua. Kata kerja bahasa-bahasa Papua lebih kompleks secara morfologis. Morfem-morfem dalam struktur kata kerja merujuk pada argumen (subjek dan objek), akar kata dasar dan juga sistem waktu (TAM). Morfem-morfem terikat pada kata kerja, yaitu yang merujuk pada penanda orang dan penanda waktu, akan selalu berubah berdasarkan perubahan subjek dan objek dan juga perubahan waktu sebagaimana dicontohkan di bawah ini:

Western Dani (Papua - Trans-New Guinea) (Barclay, 2008:275)
(9) K-agaaluk
nda'-na-gagerak
2S.PO-anak
lahir-ST- PA3.3S

'Anakmu sudah lahir'

Sedangkan kata kerja bahasa-bahasa Austronesia lebih sederhana secara morfologis. Pada umumnya, hanya subjek yang berafiksasi ke kata kerja. Perubahan pada kata kerja hanya berlaku jika subjek berubah, sebagaimana contoh dalam bahasa Ambai (Silzer, 1981: 36) ini:
(10) Tomi
d-an
rando
Tomi 3s-makan
banana
'Tomi makan pisang'

Bahasa Meyah - bahasa Papua di bagian Timur Kepala Burung Papua - memiliki ciri kata kerja yang hampir sama dengan bahasa Austronesia. Bahasa ini memiliki sistem morfologis yang sederhana sebagaimana dicontohkan di bawah ini.

Meyah (Papuan - Eastern Bird's Head) (Gravelle, 2002:140)

(11) Di-esiri jah

1SG-jatuh ke

'Saya jatuh ke bawah'

Kedua rumpun - Austronesia dan Papua - memiliki sistem morfologi kata benda yang sederhana, terutama dalam bentuk kepemilikan. Kedua rumpun bahasa ini memiliki sistem alienable dan inalienable yang ditunjukkan pada contoh di bawah ini.

Lower Grand Valley Dani (Papuan - Trans-New Guinea)
(12) a. Nin-opase
(inalienable)
1PL-ayah
'Ayah kita'
b. *nit opase
1PL ayah


(13) a. su 'kantung'

b. na-su

1SG-kantung

'kantungku'

(alienable)

Pada contoh (12a), bentuk kepemilikan sangat terikat dan tidak bisa dipisahkan antara morfem yang merujuk pada orang dan benda. Jika dipisahkan, maka bentuk itu tidak berterima secara gramatika sebagaimana dicontohkan pada (12b). Sedangkan bentuk tidak terikat memiliki kata dasar yang bebas seperti contoh (13a), dan menjadi bentuk tak terikat seperti contoh (13b).

Bahasa-bahasa Austronesia juga memiliki bentuk yang sama sebagaimana dicontohkan dalam bahasa Wooi (Sawaki, 2017).

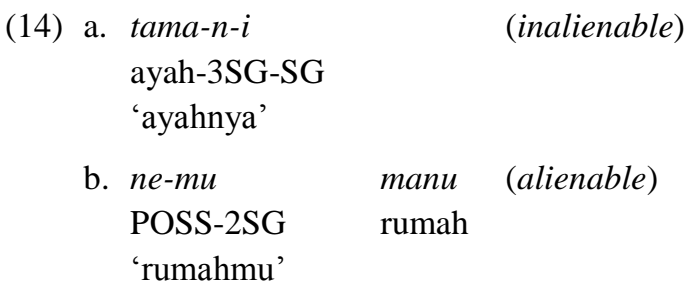

Kata-kata yang masuk dalam kelompok terikat (inalienable) sebagaimana dicontohkan pada (14a) adalah anggota tubuh (body parts) dan anggota keluarga (kinship terms), sedangkan yang masuk dalam kelompok tak terikat (alienable), seperti pada contoh (14b), adalah kata benda pada umumnya (common nouns).

Sistem pronominal bahasa-bahasa Austronesia dan Papua pada umumnya terdiri dari dua bentuk morfologi, yaitu pronominal bebas dan pronominal terikat. Untuk pronominal bebas bahasa-bahasa Austronesia dan Papua menunjukkan perbedaan, terutama yang berhubungan dengan sistem number (jumlah) dan sistem eksklusif/inklusif. Kebanyakan bahasa Papua hanya memiliki dua sistem number (jumlah), yaitu tunggal (singular) dan jamak (plural). Selain itu, bahasa-bahasa tersebut juga tidak mengenal sistem eksklusif/inklusif sebagaimana dalam bahasa LGVD (Sawaki, 2002).

Tabel 4. Kata ganti orang dalam bahasa Dani (Sawaki, 2002)

\begin{tabular}{c|c|c}
\hline Orang & Tunggal & Jamak \\
\hline 1 & an & nit \\
\hline 2 & hat & hit \\
\hline 3 & at & it \\
\hline
\end{tabular}

Bahasa-bahasa Austronesia memiliki sistem pronominal yang sedikit lebih kompleks. Bahasabahasa ini memiliki sistem number (jumlah) yang lebih kompleks yaitu, tunggal (singular), dual, trial, sedikit (pauca) dan jamak (plural), serta bentuk eksklusif/inklusif pada orang pertama yang bukan tunggal, sebagaimana dicontohkan dalam bahasa Wooi dan Ambai.

Tabel 5. Kata ganti orang dalam bahasa Wooi (Sawaki, 2017)

\begin{tabular}{c|c|c|c}
\hline Orang & Tunggal & Dual & Jamak \\
\hline 1.EKS & $y a$ & aru & ama \\
\hline 1.INK & & taru & tata \\
\hline 2 & $a u$ & maru & mia \\
\hline 3 & $i$ & haru & hnia \\
\hline
\end{tabular}


Tabel 6. Kata ganti orang bahasa Ambai (Karubaba, 2008)

\begin{tabular}{c|c|c|c|c}
\hline Orang & Tunggal & Dual & Trial & Jamak \\
\hline 1.EKS & ja:u & a:uru & antoru & amea \\
\hline 1.INK & & turu & totoru & tata \\
\hline 2 & wa:u & muru & muntoru & mea \\
\hline 3 & $i$ & uru & coru & ea \\
\hline
\end{tabular}

Beberapa bahasa di Kepala Burung Tanah Papua seperti bahasa Tehit, Moi, Maybrat, Abun, Mpur, Meyah, Sougb, Hatam, dan Mansim mempunyai kesamaan dengan bahasa Austronesia tetapi ada perbedaan bentuk pronominal gender pada orang ketiga tunggal, yaitu antara laki-laki (male) dan perempuan (female), selain terdapat bentuk number dual dan eksklusif/inklusif, sebagaimana contoh kata ganti orang dalam bahasa Meyah (Gravelle, 2004:74) dan bahasa Maybrat (Dol, 1999:68).

Tabel 7. Berbagai bentuk kata ganti orang dalam bahasa Meyah (Gravelle, 2004:74)

\begin{tabular}{|l|l|l|l|l|l|}
\hline & Bebas & Prefix & Clitic & Possessive & Reflexive \\
\hline 1SG & didif & di- & $-i d$ & dedin & di-esinsa \\
\hline 2SG & bua & bi- & $-i b$ & bebin & bi-esinsa \\
\hline 3SG & ofa & $O$ & $O$ & efen & O-esinsa \\
\hline 1DU.INC & nagif & $n a-$ & $-n a$ & nafnan & na-esinsa \\
\hline 1DU.EXC & magif & ma- & $-m a$ & mafnan & ma-esinsa \\
\hline 2/3DU & goga & ge- & - -irga & gegan & ge-esinsa \\
\hline 1PL.INC & mimif & mi- & $-m i$ & mifmin & mi-esinsa \\
\hline 1PL.EXC & memef & me- & $-m e$ & mefnen & me-esinsa \\
\hline 2PL & iwa & $i$ - & $-i$ & yeyin & i-esinsa \\
\hline 3PL & rua & ri- & $-i r$ & rerin & ri-esinsa \\
\hline
\end{tabular}

Tabel 8. Kata ganti orang dalam bahasa Maybrat (Dol, 1999:68)

\begin{tabular}{|l|l|l|l|}
\hline Number & Person & Free form & Bound form \\
\hline Singular & 1 & tuo & $t$ - \\
\hline & 2 & nuo & $n$ - \\
\hline & 3 Male & ait & $y$ - \\
\hline & 3 Female & au & $m$ - \\
\hline Plural & 1 & amu & $p$ - \\
\hline & 2 & anu & $n$ - \\
\hline & 3 & ana & $m$ - \\
\hline
\end{tabular}

Selain bentuk pronominal bebas (free pronouns), terdapat pula bentuk pronominal terikat (bound pronouns) yang berafiksasi ke kelas kata lain seperti kata kerja, kata benda, dll. Bentuk pronominal terikat ini sangat beragam, mulai dari bentuk yang sangat kompleks secara morfologis seperti yang ada dalam bahasa-bahasa Papua Trans-New Guinea (Dani, Yali, Sentani, Mee, Asmat, dll). Pada bahasa-bahasa ini, bentuk pronomina terikat berinteraksi secara morfologis dengan bentuk waktu sehingga pronominanya akan berubah-ubah sesuai dengan bentuk waktunya, terutama pronomina terikat yang merujuk pada subjek. Pronomina objek lebih stabil dan tidak berubah-ubah karena bentuk waktu. Bentuk pronomina terikat yang lebih sederhana ditemukan pada bahasa-bahasa Papua di Kepala Burung (Meyah, Hatam, Sougb, Maybrat, Moi, dll) dan juga pada bahasa-bahasa Austronesia di pesisir pantai utara Tanah Papua 
(Wooi, Ambai, Biak, Wandamen, Waropen, Moor, Yaur, dll). Pada bahasa-bahasa ini, hanya pronominal subjek yang berafiksasi dengan kata kerja sedangkan objek biasanya dalam bentuk pronomina bebas dan berdiri sendiri. Sistem ini dapat dilihat pada contoh-contoh yang diberikan di atas terutama bentuk pronominal terikat penanda subjek, objek, dan kepemilikan.

Pronominal ikutan (inclusory pronominal) juga menjadi ciri bahasa-bahasa di Papua terutama bahasa Austronesia. Pronominal ikutan berfungsi memodifikasi frasa nominal sebagai pemberi tanda person/number. Pronominal ikutan ini dibagi menjadi dua tipe yaitu tipe sintaksis yang umum dan tipe morfologis sebagaimana digambarkan dalam bahasa Wooi (Sawaki, 2017):

Tipe sintaksis:

\begin{tabular}{lccc} 
(15) $\begin{array}{l}\text { Markus } \\
\text { markus }\end{array}$ ti-rora & Jon & hia \\
Markus & 3SG-pukul & John & 3PL \\
\multicolumn{4}{l}{ 'Markus memukul John dan teman-teman' }
\end{tabular}

Tipe morfologi:

(16) Agus hemararising tata
Agus he-t-mararising tata
Agus 3PL-PL-suka 1PL.INC
'Agus dan teman-teman menyukai kita'

Melayu Papua juga memiliki bentuk pronominal ikutan ini (inclusory pronominal) yang merefleksikan kontak bahasa yang telah terjadi antara bahasa Melayu Papua dan bahasa-bahas Asutronesia di Papua sebagaimana di contohkan di bawah ini:

(17) Mama

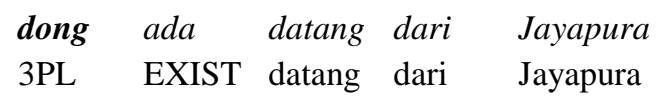

Ibu 3PL EXIST datang dari Jayapura

'Ibu dan orang lain datang dari Jayapura'

$\begin{array}{llllll}\text { (18) } \text { Orang } & \text { dong } & \text { datang bawa } & \text { makanan untuk Agus } & \text { dong } \\ \text { Man } & \text { 3PL } & \text { datang membawa } & \text { makanan untuk Agus } & 3 \mathrm{SG}\end{array}$

'Orang-orang datang dan membawa makanan untuk Agus dan teman-teman'

Kata kerja berseri (serial verbs) juga merupakan ciri umum bahasa-bahasa di Papua. Secara semantik, kata kerja berseri menggambarkan runtutan aktifitas yang berkesinambungan dalam satu predikat sebagaimana dicontohkan dalam bahasa Meyah (Dol, 2004:237).

(19) ri-agob ef marfeb eij 3PL-bunuh gantung tali buang

'Mereka membunuh kanguru pohon, mengikatnya dan mengantungnya (di punggungnya).

Kata kerja berseri dapat pula dilihat dalam bahasa Melayu Papua di bawah ini:

(20) Dong mo pi lari bawa pulang sa pu wang tadi 3PL ingin pergi berlari bawa kembali $1 \mathrm{SG}$ POSS uang tadi 'Mereka ingin pergi berlari membawa kembali uang tadi'

Meskipun demikian, kata kerja berseri dalam bahasa Papua dan Austronesia berbeda dalam konstruksi gramatikanya. Pada umumnya, bahasa-bahasa Papua memiliki konstruksi morfologi di mana morfem-morfem kata kerja terstruktur secara morfologis menjadi satu kata kerja yang kompleks. Sedangkan kata kerja berseri dalam bahasa-bahasa Austronesia pada umumnya tersusun secara sintaksis sebagaimana yang ditunjukkan pada contoh (19) dan (20) di atas. 
Dalam struktur frasa adposisi, bahasa-bahasa Papua cenderung lebih menganut struktur posposisi, sedangkan bahasa-bahasa Austronesia menganut struktur preposisi. Dalam bahasa Dani, frasa nominal yang menunjukkan lokasi/tempat ditandai dengan posposisi seperti pada contoh (21) dan (22).

(21) Uwe-ma

Uwe-LOC

'di sungai Uwe'

(22) Wusalak-ma

Wusalak-LOC

'di kampung Wusalak'

Bahasa-bahasa Papua kelompok Papua Barat di Kepala Burung berbeda dari bahasa Trans New Guinea seperti bahasa Dani. Bahasa-bahasa ini menggunakan preposisi untuk menunjukkan lokasi/tempat, sebagaimana dicontohkan dalam bahasa Maybrat dan Hatam.

Maybrat (Dol, 1999:130)

(23) Frok to Kumurkek

Dia (laki-laki).tiba di Kumurkek

'Dia (laki-laki) tiba di Kumurkek'

Hatam (Reesink, 1999:114)

(24) di i-bong ei nungugw Ndo ni-behei.

[REL 3PL-tinggal LOC gunung Arfak 3SG-bawah] Rc

'Saya akan bercerita tentang suku yang mendiami kaki pegunungan Arfak'

Bahasa-bahasa Austronesia juga menggunakan preposisi dari pada posposisi. Dalam bahasa Biak dan bahasa Wamesa/Wandamen, penggunaan preposisi yang menunjukkan lokasi atau tempat seperti pada contoh berikut.

Biak (Mofu, 2008:149)

$\begin{array}{llll}\text { (25) Susan } & \text { imbran } & \text { be } & \text { rumfarkor } \\ \text { Susan } & \text { i-mbran } & \text { be } & \text { rumfarkor } \\ \text { Susan } & \text { 3SG-jalan } & \text { ke } & \text { sekolah }\end{array}$

'Susan jalan ke sekolah'

Wamesa/Wandamen (Karubuy, 2011:46)

\begin{tabular}{|c|c|c|c|c|}
\hline (26) $Y a$ & yosa & $n a$ & anio & nei \\
\hline Ya & $\mathbf{y}$-osa & na & anio & nei \\
\hline $1 \mathrm{SG}$ & 1SG-berdiri & di & rumah & PROX \\
\hline
\end{tabular}

'Saya berdiri di rumah ini'

Yang menarik bahwa di bahasa Austronesia yang memiliki kontak intensif dengan bahasa Papua, terutama bahasa Asutronesia di sekitar kota Jayapura, penggunaan preposisi tidak berlaku. Yang digunakan adalah posposisi menyerupai bahasa-bahasa Papua, sebagaimana di dalam bahasa Tobati (Donohue, 2002:195).

$\begin{array}{lll}\text { (27) Nehu } & \text { tobwadic-ad } & \text { wi-acad. } \\ \text { ISG } & \text { Tobati-ALL } & \text { pergi-IRR }\end{array}$

'Saya ingin pergi ke Tobati'

Untuk kelas kata benda, baik bahasa Papua dan bahasa Austronesia di Papua memiliki struktur morfologis yang sederhana, selain struktur bentuk kepunyaan yang telah dijelaskan di 
atas, kedua bahasa ini juga memiliki bentuk lain seperti morfem yang merujuk kepada perbedaan gender, juga penanda kasus (case). Di bahasa Yali (Sawaki 1998), untuk memberikan tanda ergatif subjek sebagai penanda kasus agentif, ditandai dengan sufiks -en di pronominal atau nominal, seperti contoh (26).

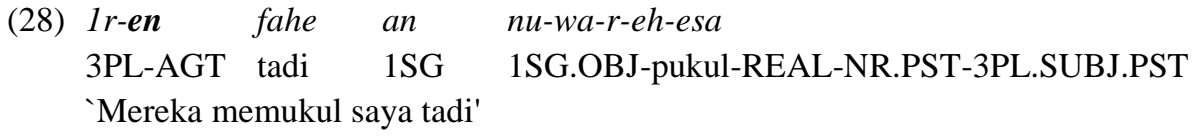

Penanda kasus agentif dengan sufiks -en hanya berlaku untuk kata kerja yang memiliki tingkat transitif yang kuat seperti kata kerja pukul, bunuh, dorong, dan angkat. Kata kerja yang tingkat transitifnya rendah, sufiks -en menjadi pilihan dipakai atau tidak dan bahkan tidak digunakan seperti kata kerja intransitive ataupun kata kerja transitif yang tidak memgambarkan kontak fisik secara langsung seperti diilustrasikan pada contoh (29).

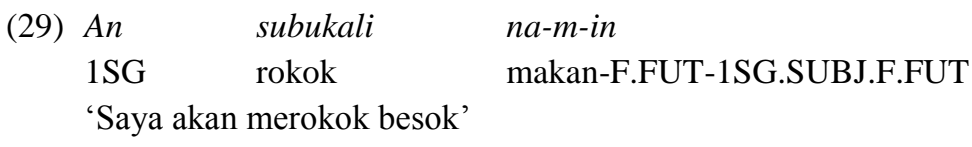

Bentuk relasi gramatikal juga menunjukkan perbedaan antara bahasa Papua dan bahasa Austronesia. Bahasa-bahasa Papua pada umumnya menganut relasi gramatikal Ergatif-Absolutif pada level sintaksis dan relasi gramatikal aktif-statif dalam morfologi kata kerja. Sedangkan bahasa-bahasa Austronesia lebih cenderung memiliki ciri relasi gramatikal nominatif-akusatif. Struktur argumen, yaitu struktur Subjek, Objek dan Oblik sangat ketat dan tetap. Posisi subjek, objek dan oblik tidak dapat ditukar dengan bebas.

Dalam penggunaan penghubung antar klausa, bahasa Austronesia kebanyakan menggunakan kata penghubung yang berdiri sendiri secara sintaksis sedangkan bahasa-bahasa Papua terutama dari rumpun Trans-New Guinea lebih banyak menggunakan switch-reference mechanism dan atau mekanisme kerekatan antara klausa (clause chaining) sebagaimana yang ditunjukan oleh bahasa-bahasa seperti bahasa Yali, Dani, Asmat, Awyu, dll.

Bahasa Wooi, Austronesia (Sawaki, 2017:340)

\begin{tabular}{clllll} 
(30) & \multicolumn{2}{l}{ Ariang katung } & nei & hioha & spatu \\
ariang & katung & ne-i & ti-hoha & spatu ne \\
anak & kecil & PRX-SG & 3SG-menaruh & sepatu & PRX-NSG \\
ainte & nya & ma & hia & & \\
marainte & ti-na & mara & ti-ha & & \\
kemudian & 3SG-tinggal & kemudian & 3SG-panggil & &
\end{tabular}

'...anak kecil itu menaruh sepatunya dan kemudian dia terus memanggil...' [Frog Story2_JK 035036]

Bahasa Walak, Papua (Gombo, 2018)

\begin{tabular}{|c|c|c|}
\hline Ir & imbirak in-il-uk & agula-g-a-rik \\
\hline Mereka & berdua 3PL-mata-SEQ & bangun-PPT-3PL-SS \\
\hline $\begin{array}{l}\text { in-il } \\
\text { 3PL-mata }\end{array}$ & $\begin{array}{l}k e-g-a \\
\text { melihat-PPT-3PL }\end{array}$ & $\begin{array}{l}\text { mendek... } \\
\text { tetapi..... }\end{array}$ \\
\hline
\end{tabular}

'Mereka berdua bangun dan melihat tetapi...' (Frog Story_Wainus)

Dalam bahasa Wooi (30), kata penghubung ainte 'kemudian' dan ma 'kemudian' digunakan untuk menghubungkan dua atau lebih klausa paralel. Sedangkan dalam bahasa 
Walak, untuk menghubungkan dua atau lebih klausa digunakan penanda morfologis yaitu penanda sekuensial (SEQ), sufiks $-u k$ 'SEQ' dan penanda switch reference yaitu sufiks -rik 'SS' yang melekat pada kata kerja.

Dalam konteks penggunaan kalimat, alternatif sistem voice (voice system) bahasabahasa di Papua, baik bahasa Austronesia maupun bahasa Papua, tidak mengenal sistem pasif. Strategi pasif digantikan dengan konteks pragmatik topikalisasi di mana argumen objek diletakkan di depan kalimat tetapi struktur subjek dan kata kerja tetap dipertahankan. Posisi sintaksis objek yang mengikuti kata kerja diisi oleh kata ganti orang (pronominal copy) yang merujuk pada objek yang pindah ke depan kalimat.

Bahasa Wooi (Sawaki, 2017)

\begin{tabular}{|c|c|c|c|c|c|c|}
\hline (32) Ariang & wampai & Jon & cong & $w a$ & $n e i$ & vei \\
\hline ariang & wang-pa-i & Jon & ti-ong & wa & ne-i & $v e=i$ \\
\hline anak & itu.2-DIST-SG & John & 3SG-buat & perahu & PRX-SG & untuk=3SG \\
\hline
\end{tabular}

'Anak itu John buatkan perahu untuknya'

Bahasa-bahasa di Papua mengenal beberapa sistem hitung (counting system). Sistem hitung ini sebenarnya tidak unik bagi bahasa-bahasa di New Guinea secara umum. Sistem hitung yang umum digunakan adalah sistem hitung angka (numeral system) dan sistem hitung dengan menggunakan anggota tubuh (body counting system). Sistem angka banyak digunakan dalam bahasa-bahasa Austronesia seperti bahasa-bahasa di Teluk Cenderawasih, seperti bahasa Wooi, Biak, dan Waropen. Sedangkan bahasa-bahasa Papua lebih banyak menggunakan sistem hitung anggota tubuh. Untuk angka dasar yang menjadi basis dalam hitungan juga bervariasi tetapi pada umumnya mulai angka dasar dua (binary) seperti dalam bahasa Walak, angka dasar lima (quinary) seperti bahasa Yali (Trans-New Guinea) dan Mpur (West Papua), sampai angka dasar kombinasi sepuluh (decimal) dan dua puluh (vigesimal) seperti bahasa Wooi dan Waropen (Austronesia, Teluk Cenderawasih).

\section{KESIMPULAN}

Secara linguistik historis dan tipologi bahasa, bahasa-bahasa di Papua digolongkan dalam dua kelompok besar yaitu bahasa-bahasa Austronesia dan non-Austronesia. Bahasa Austronesia lebih dikenal dengan tipologi struktur klausa yaitu SPO. Sedangkan, bahasa non-Austronesia atau lebih dikenal dengan istilah bahasa Papua memiliki tipologi struktur klausa SOP. Struktur klausa ini merupakan dasar yang membedakan bahasa-bahasa kelompok Austronesia dan nonAustronesia (Papua).

Kedua kelompok bahasa ini juga memiliki keragaman struktur gramatika yang berlainan seperti struktur fonologi, morfologi, sintaksis, semantik, dan pragmatik. Perbedaan-perbedaan ini merupakan ciri-ciri utama di tingkat kelompok bahasa. Meskipun demikian terdapat pula ciri-ciri khusus gramatika yang terdapat di setiap individu bahasa baik yang berada di dalam kelompok Austronesia dan non-Austronesia. Sebagai contoh bahasa Tobati yang adalah bahasa Austronesia dari kelompok Oceania tetapi bahasa ini lebih mengenal penggunaan posposisi daripada preposisi. Struktur posposisi ini lebih mengikuti struktur adposisi bahasa nonAustronesia.

Kontak bahasa yang telah lama terjadi antara bahasa Austronesia dan non-Austronesia baik di wilayah Jayapura maupun di wilayah Kepala Burung Papua membuat bahasa-bahas Austronesia di Jayapura memiliki banyak ciri-ciri bahasa non-Austronesia dan bahasa-bahasa 
non-Austronesia (Papua) di Kepala Burung memiliki banyak ciri-ciri linguistik yang mirip dengan bahasa Austronesia.

Keragaman ini membuat Papua merupakan wilayah linguistis yang sangat tinggi tingkat keragamannya. Keragaman ini perlu dibuat kajian sehingga bisa menambah perbendaharaan hasil-hasil penelitian yang akan menambah kekayaan intelektual kebahasaan untuk tujuan ilmu pengembangan pengetahuan.

\section{CATATAN}

* Penulis berterima kasih kepada mitra bestari yang telah memberikan saran-saran untuk perbaikan artikel ini.

\section{DAFTAR PUSTAKA}

Barclay, P. (2008). A Grammar of Western Dani. Lincom Europa. Munchen.

Blust, R. (1993). Austronesian sibling terms and culture history. Dalam Brijdragen tot de Taal-, Land- en Volkenkunde 149, 1. 22-76. Leiden.

Blust, R. (2009). The Austronesian languages. Camberra: Pacific Linguistics.

Clouse, D.A. (1993). Languages of western Lakes Plains. Dalam IRIAN: Buletin of Irian Jaya, Vol. XXI: 1-32.

Croft, W. (2003). Typology and universals. Cambridge: Cambridge University Press.

Dixon, R. M. W. (2010). Basic linguistic theory. Grammatical topic. Oxford: Oxford University Press.

Dol, P. (2007). A grammar of Maybrat. A language of the Bird's Head Peninsula, Papua Province, Indonesia. Canberra: Pacific Linguistics.

Donohue, M. (2002). Tobati. Dalam J. Lynch, M. Ross \& T. Crowley (eds.). Dalam The Oceania languages. New York: Curzon. 186-203.

. (2011). Papuan Malay of New Guinea. Melanesian influence on verb and clause structure. Dalam C. Lefebvre (ed.). Creoles, their substrates, and language typology. 413-435. John Benjamins Publishing Company.

Foley, W. A. (1986). The Papuan languages of New Guinea. Cambridge: Cambridge University Press.

. (2000). The languages of New Guinea. Dalam Annual Review of Anthropology, 29: $357-404$

Gombo, W. (2018). Pronominal marking system in Walak. Skripsi. Fakultas Sastra dan Budaya. Universitas Papua.

Gravelle, G. (2002). Morphosyntactic properties of Meyah word classes. Dalam Reesink (ed.). Languages of the eastern bird's head, 109-180. Canberra: Pacific Linguistics.

Heine, B. (1997). Cognitive foundations of grammar. Oxford: Oxford University Press.

Kamholz, D. (2014). Austronesians in Papua: Diversification and change in South HalmaheraWest New Guinea. Disertasi. Berkeley: University of California.

Karubaba, S.Y. (2008). Ambai Inflectional and Derivational Morphology. M.Phil. thesis. University of Leiden. 
Karubuy, T. (2011). Verbal morphology in Wamesa with reference to Windesi. Skripsi. Fakultas Sastra, Universitas Negeri Papua.

Klamer, M. (2002). Ten years of synchronic Austronesian linguistics (1991-2002). Dalam Lingua. 933-965.

Mofu, S. S. (2008). Biak morphosyntax. Doctoral thesis. Oxford: University of Oxford.

Patz, E. (1978). The case marking and role coding system of Numfor-Biak. Dalam Oceanic Linguistics, 17(2): 1414-161

Pawley \& Ross. (1993). Austronesian historical linguistics and culture history. Dalam Annual Review of Anthropology, 22: 425-459.

Pawley, Andrew. (2007). The origins of early Lapita culture: The testimony of historical linguistics. Dalam Stuart Bedford, Christophe Sand and Sean P. Connaughton, (eds.), Oceanic Explorations: Lapita and Western Pacific Settlement: 17-49. Canberra: ANU E Press.

Payne, T. (1997). Describing Morphosyntax. A guide for field linguists. Cambridge: Cambridge University Press.

Reesink, G. (2002). Languages of the Eastern Bird's Head. Canberra: Pacific Linguistics.

Ross, M. (1996). On the genetic affiliations of the Oceanic languages of Irian Jaya. Dalam Oceanic Linguistics, 35(2): 258-271.

Ross, M. (2004). The morphosyntactic typology of Oceanic languages. Dalam Language and Linguistics 5: 491-541.

Sawaki, Y. (1998). A comparative study of Middle Yali verbal systems and those of English. Skripsi. Universitas Cenderawasih.

. (2008). Person marking systems in Dani languages. Dalam Linguistik Indonesia, 26(2): 129-149.

. (2017). A grammar of Wooi. An Austronesian language of Yapen Island, Western New Guinea. Ph.D. thesis. Australian National University.

Silzer, P.J. (1983). Ambai: An Austronesian language of Irian Jaya, Indonesia. Disertasi. ANU. Canberra.

Søgaard, A. (2005). The semantics of possession in natural language and knowledge representation. Dalam Journal of Universal Language 6: 85-115.

Van den Heuvel, W. (2006). Biak. Description of an Austronesian language of Papua. Disertasi. Vrije Universiteit.

\footnotetext{
i Paucal adalah istilah yang merujuk pada jumlah (number) pada kata ganti orang dengan jumlah yang sedikit (bahasa Inggris: a few), yang lebih dari dua orang, tetapi tidak merujuk pada jumlah banyak (plural number) secara semantik. Kata ini biasanya digunakan untuk jumlah kurang lebih tiga atau empat orang. Ada banyak bahasa yang hanya membagi jumlah (number) pada kata ganti orang menjadi tunggal (singular), sedikit (paucal), dan banyak (plural).
} 